REMLATE DE MAALES

Campinas-SP, v. 38, n. 1, pp. 186-219, jan./jun. 2018

\title{
INDO-MOZAMBICAN INTERACTIONS WITH THE STATE (1947-1992): Civic AND Religious INSTITUTIONS IN LOURENÇO MARQUES/ MAPUTO AS Sites of ETHNic IDENTITY Affirmation AND Migratory Contestation
}

\author{
Nafeesah Allen ${ }^{1}$
}

\begin{abstract}
Using in-depth ethnographic and archival data, this study argues that over the late $2 \mathrm{O}^{\text {th }}$ century religious and civic institutions in Lourenço Marques/Maputo served as spaces of transnational identity contestation for Mozambican residents of Indian and Pakistani origin (herein referred to as "Indo-Mozambicans"). During this period, Indo--Mozambicans absorbed the aftershocks of four particular geo-political shifts in the Indian Ocean and the Lusophoneworld: Indian independence from Britain in 1947, the annexation of Portuguese India in 1961, Mozambican independence in 1975, and the Mozambican civil war from 1977 to 1992. This study explores how representative organizations changed their name, membership, and purpose over this period to ensure their institutional survival and to solidify their value as a transnational site of cultural significance. Institutional resilience is contrasted across Indo-Mozambican associations of varying faiths with special attention given to the institution of the Comunidade Hindu (herein referred to as "Comunidade"). In light of forced migration, successive decolonization movements, and fluctuating citizenship rights, the Comunidade's continued existence today presents a valuable case study in the survival tactics employed by ethno-religious organizations to overcome pervasive vulnerability and to support members through serial insecurity. Individual members' oral narratives articulate how ethnic sub-identity was defined and divided as political and social shifts in the Indian Ocean and Lusophone worlds collided in the late $2 \mathrm{O}^{\text {th }}$ century. Indo-Mozambican associations served as transnational sites where ethnic identity and migratory agency were cyclically constructed and deconstructed to respond to and cope with federal power structures and local demographics.
\end{abstract}

Keywords: Mozambique; migration; Indian Diaspora.

1 Ph.D candidate, University of the Witwatersrand, African Centre for Migration \& Society, South Africa: 1119223@students.wits.ac.za. 


\section{INTRODUCTION}

From 2014 to 2017, I conducted extensive archival and ethnographic research in mainland Maputo to analyze Indo-Mozambican waves of migration and the resulting landscapes of identity that emerged throughout the late twentieth century. The larger study expands on existing Indian Ocean historiography and southern African ethnographic literature (GUPTA, 2010; CAMPBELL, 2004; MULLOO, 2007) to explore twentieth century migration patterns and sub-identities present within Mozambique's communities of Indian subcontinent origin (hereafter referred to as "Indo-Mozambicans"). This study just scratched the surface of subaltern identity and transnational migration within Maputo's specific urban context, yet the content reveals the fault lines of identity and tripwires of migration used by Indo-Mozambicans as coping mechanisms in the $2 \mathrm{O}^{\text {th }}$ century. Oral narratives captured here show how these subaltern individuals in the country's capital remembered the period of 1947-1992 as a time of unprecedented social, geopolitical, and economic pressure.

I anticipated that various moments between the end of the British empire in India (1947) and the end of Mozambique's civil war (1992) would be remembered by Indo-Mozambicans for their geopolitical significance to the Indian Ocean world and thus would also be causally linked to the use of migration as a survival tool to cope with the uncertainty of the time. My preconceptions hinted that the creation of Pakistan in 1947, the founding of Bangladesh in 1971, the expulsion of Asians from Uganda in 1972, and the end of South African apartheid in 1991 would be formative historical moments affecting not only Indo-Mozambicans' migratory patterns, but also their sense of cultural identity. Research confirmed, however, the periphery nature of Indian Ocean fluxes and southern African regional interconnectivity; instead, Portuguese colonial networks held primacy. The end of the British Empire in 1947, the end of the Portuguese empire in India in 1961, Mozambican independence from Portugal in 1975, and the Mozambican civil war from 1977-1992 proved to be the most important political catalysts for migration and identity formation in the particular and contemporary history of Indo-Mozambicans. Individual oral narratives and collective archival data herein expose the complex intersection of Lusophone colonial and Indian subcontinent origin metanarratives, as manifested in civic associations established to help individuals navigate the terrain. 
This study is situated in Mozambique's $20^{\text {th }}$ century capital, called Lourenço Marques (LM) before 1975 and thereafter Maputo. Though both refer to the same urban landscape, naming signals temporal and thus political differences. When the city is referred to as LM, Portuguese colonialism was underway. When Maputo is used, the country was independent. By virtue of this study being conducted in LM/Maputo, the ethnographic sample was comprised of people who did not emigrate permanently, if atall. Thus, thevery site of intellectual discourse in defining macro-level causes of migration, naming the micro-level identities, and analyzing individuals' agency to determine their own identity and location during this particularly volatile period in Mozambican history was situated precisely within the liminal context of those who stayed behind. Oral histories of Indo-Mozambicans who stayed behind in Lourenço Marques/ Maputo from 1947-1992 showed the constant negotiations of location and loyalty allowed them to manage up and down shifting social hierarchies.
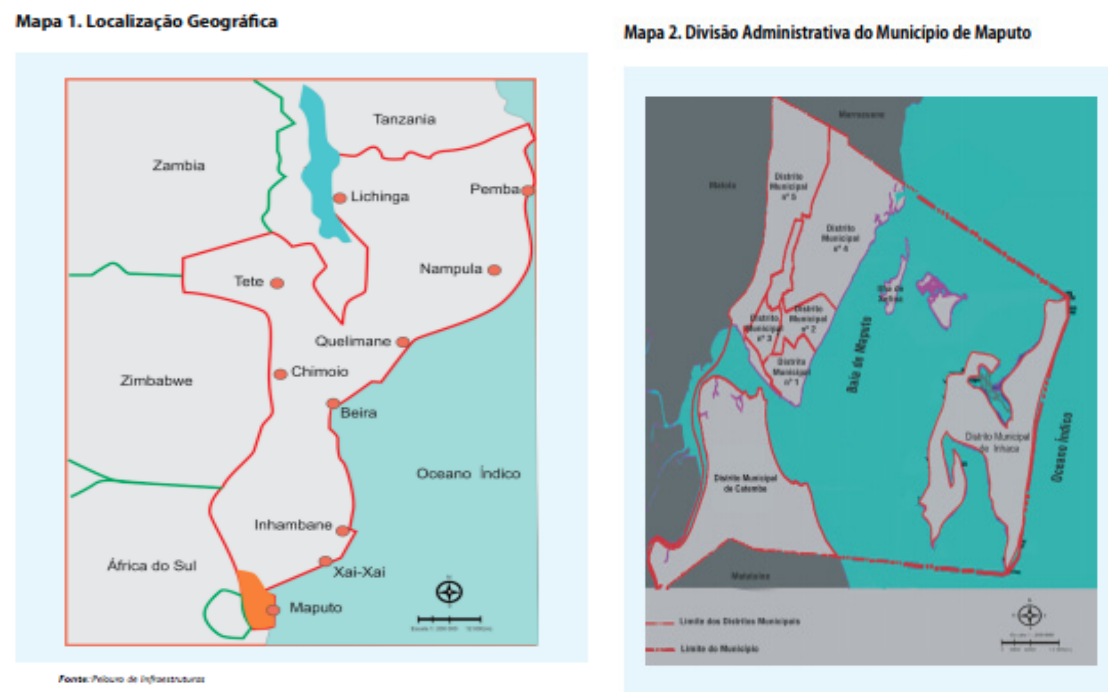

Figure 1: Municipality of Maputo's 2007.

Source: Mozambique (2007, pp. 10-11). 


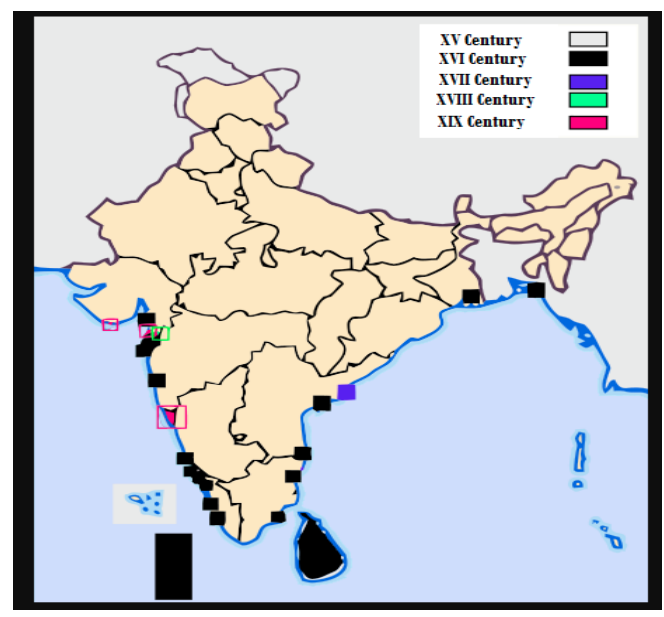

Figure 2: Portugal's Indian Territories (pink boxes refer to areas mentioned herein). Source: Antunes (2012, [s.p.]).

A thorough review of Mozambique's national history shows an Indo-Mozambican population framed by mercantile connections and a deep sense of transnational ownership over migration throughout the Indian Ocean. Indo-Mozambicans form a distinctly powerful and nebulous group that has maintained a historical permanence in Mozambique dating back to the $13^{\text {th }}$ century (HROMNÍK, 1977); Indo-Mozambican individuals are rarely regarded as immigrants - no matter how recently they arrived - but that does not mean that they always belong. In the $20^{\text {th }}$ century context, they have served as economic adversaries to Portuguese business interests, as well as political interlocutors between the metropole and the colony. This has made them both powerful social actors, as well as vulnerable and visible minorities, as powers shifted from Portuguese colonial to Black majority rule.

\section{INSTITUTIONS AS BATTLEGROUNDS FOR TRANSNATIONAL IDENTITY AFFIRMATION}

In early 2016, when I told a Mozambican friend about my study, he casually joked that, "There is a common saying about Indians. When the Portuguese were in power, it was Whites on top, Indians in the middle, and Blacks on the bottom. When independence came, it was Blacks on the top, Indians in the middle, and Whites on the bottom. Not much 
changed for Indians" (MACARINGUE, [s.p.]). What I found was that Indo-Mozambican resistance and survival strategies to stabilize themselves as social and political intermediaries over time was fascinatingly more complex than that. Indo-Mozambican civic and religious associations served an important role, advocating for individual and collective ethnic retentions in this Diasporic context.

The permanence of Indo-Mozambican presence in the national capital was not a default choice or the result of migratory apathy. Instead, staying behind in Mozambique over the $20^{\text {th }}$ century was the culmination of successfully implemented survival strategies to maintain their presence, despite multifaceted attempts by the State to force or incentivize their emigration. During the period between 1947 and 1992, Indo-Mozambicans experienced five different self-rule movements. Thus, naming their nationality became an important factor in their self-identity. Even those who stayed behind in LM/Maputo found their nationality in flux, perhaps making them Mozambican in social terms, but Pakistani or British or Portuguese by citizenship. The choice to obtain or maintain one nationality as an identifier (or not) became a question of political and migratory agency. It identified not only where individuals were located, but where they could, perhaps one day, relocate if needed. While most interviewees did not individually verbalize experiencing racism, the archival data and the collection of the oral narratives show that between 1947 and 1992 there were constant demands that Indo-Mozambicans locate and name themselves for African and European's social and political gaze.

Because of how rapidly State and civic actors changed in person and in politics over the five decades in question, no single source could be inherently relied upon to explore how Indo-Mozambicans individually or collectively interacted with the State. Each decade's historical moments distinctly affected a different sub-group of "Asians" or "Indians", as they were commonly referred to at the time. How identities were articulated and how civic organizations framed their advocacy shifted based on federal power structures and local demographics. With this in mind, I focused a specific part of the field work on collecting documents about civic associations' member rolls, religious groups' correspondence with State actors, and institutions' interactions with the State on behalf of its membership; such historical records relate attempts to stage collective cohesion in the face of shifting social and political benefit structures. 
Though originally framed as educational or fraternal institutions, over time civic organizations became one of the many tools of representation and agency at the disposal of Indo-Mozambicans. Their day to day activities served the educative function of perpetuating ethnic continuity, especially in the performative arts, linguistic preservation and religious traditions. The cultural value of such organizations in a Diasporic context is particularly vital for self-affirmation of individuals; the ways that such organizations advocated for its members also played a role in the selfaffirmation process. It was under the rubric of these organizations that many records have been preserved today and provide documentation of correspondence between Indo-Mozambican constituent members and federal State actors - both in the colonial period with the Portuguese government, as well as after Mozambican independence.

Joaquim Maloa's (2016) thesis entitled The Urbanization of Mozambique: A Proposed Interpretation offers a short summary of both the demographics of LM and the socio-spatial divides of the early $20^{\text {th }}$ century:

The 1894 census identified among LM residents around 38 Chinese, distributed between 23 in Downtown and 15 in the Central District, principally in commerce and crafts. Also, there were 245 Indians, which corresponded to $23.14 \%$ of the white population of LM; among them 151 were Muslim and 59 were Hindu. In 1928, the number of Asians grew to around 1974 residents [...] The urban nucleus of Lourenço Marques grew as a space of "ethnic segregation", according to Mohammad A. Quader (2004), in enclaves - neighborhoods with racial, cultural and social distinctions (European and Asian). Valdemir Zamparoni (1998) wrote that, in the city, the hierarchy of races translated into territorial separation of bodies. (MALOA, 2017, pp. 133-134)

Table 1 - Distribution of professions by racial groups in Lourenço Marques in 1890

\begin{tabular}{|l|c|c|c|c|c|}
\hline $\begin{array}{l}\text { Racial Groups } \\
\text { and Professions }\end{array}$ & Yellow \% & Indian \% & White \% & Black \% & $\begin{array}{c}\text { Total/ } \\
\text { Activities \% }\end{array}$ \\
\hline $\begin{array}{l}\text { Agriculture and } \\
\text { Fisheries }\end{array}$ & 11.1 & $\mathbf{0 . 0}$ & 88.9 & 0.0 & 1.9 \\
\hline $\begin{array}{l}\text { Operations and } \\
\text { Artisan }\end{array}$ & 0.0 & $\mathbf{2 0 . 4}$ & 76.1 & 3.4 & 9.7 \\
\hline $\begin{array}{l}\text { Construction and } \\
\text { public works }\end{array}$ & 31.0 & $\mathbf{7 . 0}$ & 61.9 & 0 & 7.8 \\
\hline $\begin{array}{l}\text { Commerce and } \\
\text { Banking }\end{array}$ & 3.4 & $\mathbf{5 0 . 0}$ & 44.3 & 2.2 & 35.3 \\
\hline
\end{tabular}




\begin{tabular}{|l|c|c|c|c|c|}
\hline $\begin{array}{l}\text { Transport and } \\
\text { Communication }\end{array}$ & 0.0 & $\mathbf{0 . 0}$ & 93.5 & 6.5 & 8.5 \\
\hline $\begin{array}{l}\text { Service and Admi- } \\
\text { nistration }\end{array}$ & 0.0 & $\mathbf{2 3 . 0}$ & 72.6 & 4.2 & 12.9 \\
\hline Domestic Service & 1.1 & $\mathbf{2 7 . 0}$ & 25.9 & 45.5 & 9.4 \\
\hline Non-professional & 0.7 & $\mathbf{6 . 2}$ & 71.1 & 21.9 & 14.1 \\
\hline Population total & 4.1 & $\mathbf{2 6 . 6}$ & 59.6 & 9.6 & 100 \\
\hline
\end{tabular}

Source: Zamparoni Adaption (1989 apud MALOA, 2017, p. 137, Highlights author's own for emphasis).

Table 2 - Population of Mozambique District in 1908

\begin{tabular}{|c|c|c|c|c|c|c|c|c|}
\hline Nationality & \multicolumn{3}{|c|}{ Europeans } & \multicolumn{3}{|c|}{ Asiatics } & Africans & Total \\
\hline & Male & Female & Total & Male & Female & Total & Male/Female & \\
\hline Portuguese & 373 & 48 & 421 & 190 & 5 & 195 & 360000 & 360616 \\
\hline British & 12 & o & 12 & 563 & 57 & 620 & o & 632 \\
\hline German & 6 & o & 6 & $\mathbf{o}$ & $\mathbf{o}$ & $\mathbf{o}$ & o & 6 \\
\hline French & 4 & 8 & 12 & $\mathbf{o}$ & $\mathbf{o}$ & $\mathbf{o}$ & o & 12 \\
\hline Other & 5 & o & 5 & $\mathbf{o}$ & $\mathbf{o}$ & $\mathbf{o}$ & o & 5 \\
\hline Total & 400 & 56 & 456 & 753 & 62 & 815 & 360000 & 361271 \\
\hline
\end{tabular}

Source: RTCPM1908 (apud OISHI, 2007, p. 6-7, Highlights author's own for emphasis).

One of the coping strategies that addressed the need for in-group bonding was the proliferation of distinct ethno-religious community groups. In LM, prominent civic, ethnic, and religious organizations educated and advocated for separate and distinct Indo-Mozambican subgroups. Valdemir Zamparoni's 1999 study explores colonial racism towards Asians in LM in the early $20^{\text {th }}$ century and explores the proliferation of community groups as a coping mechanism for Asian isolation (ZAMPARONI, 1999, p. 210). Nevertheless, for a city so small, by population and space, the proliferation of diverse fraternal organizations represented institutional examples of fractured identities within the already limited Indo-Mozambican population.

Even within the small cohort of Indo-Mozambicans in the capital, individuals circulated in the same urban center at similar times, yet few lives genuinely intersected. They co-existed in cordial proximity, however, and affinity and religious groups emerged to advocate for constituents and broker intergroup rivalries. In turn, evidence suggests that Indo-Mozambicans became adept at self-identifying for external gaze only 
when it offered tangible benefits. Instead, most erred on the side of silence and self-censorship to assure their economic and social survival.

Susana Pereira Bastos' work on identity construction in the Portuguese Empire directly speaks to the Hindu Comunidade's political shifts in positionality as clever manifestations of their members' understanding of race politics. Whether in word or in deed, it was well understood that social and political conflict could not be directly addressed, without severe State reprisal. Thus, the institutional shifts in the Comunidade were both a reflection of and a reaction to the pressures placed on individuals to cope with residing in a society that was at times outright confrontational to their very presence. Bastos' words best summarize and contextualize these inconsistencies and counterintuitive relationships.

\begin{abstract}
Conscious of the advantages that could accrue from their definition as close collaborators of the regime, Hindus periodically gave the Portuguese State "proof", exhibited in the Portuguese and British press, of their gratitude and political subordination. Among the most highly recognized were the confirmation of racial and religious tolerance as a moving force of the Portuguese Colonial Empire, the inclusion of Portuguese language instruction among the basic objectives of the main Hindu association in the colony (created in Lourenço Marques in 1933) and, more importantly, the numerous demonstrations of deference, admiration and homage to the Colonial Government (for instance, by placing portraits of the highest political figures of the time in the main hall of the Veda Mandir, inaugurated in the capital city of Mozambique in 1938).

Despite the fact that the leaders of Hindu associations preferred, in public, to make statements such as "we Hindus see the Portuguese as the most welcoming of all the lords of the land", the majority of the Hindu population recognized that there was much discrimination of whites towards Indians. (BASTOS, 2006, p. 14)
\end{abstract}

Justas Indo-Mozambican institutions served as mediums of protection against State actors, they also served as advocacy vehicles to seek benefits and access from those same State actors. The arguments of Jeanne Marie Penvenne's book African Workers and Colonial Racism is an exhaustive study on urban employment and racism in Mozambique have proven relevant to this study's assessment of identity group belonging amongst Indo-Mozambicans. While Penvenne's exhaustive text principally focuses on belonging within Black African ethnic groups, her analysis is just as relevant and accurate to the experience of Indo-Mozambicans residing in and frequenting civic institutions in LM. In-group belonging served as a source of social currency, lubricating interpersonal relationships and 
often reaping transactional benefits for the represented community in return.

Ethnicity emerged as a relational base from which individuals negotiated identities, interests, and advantage in the competition for claims on valued resources. The knowledge and deployment of language, protocol, and symbols figured in any individual's ability to negotiate claims on resources. In the urban context market intelligence, capital, shelter, and, most of all, good jobs were valued resources. Claims of "belonging" to the specific group or "relationship" to the specific individual who controlled such resources were often the key to access. Sometimes shared language, protocol, and symbols emerged from childhood experience in rural Sul do Save - that kind of sharing is familiarly associated with ethnicity. But shared language, protocol, and symbols also developed around workplace experience among urban groups from diverse rural backgrounds. Membership in sports groups, social and church associations, or mutual aid and savings groups at the workplace could also foster claims of "belonging", and provide avenues of information, assistance, and dependency. (PENVENNE, 1995, p. 9)

Through these institutions, rhetorical correspondence with the State showed alliance with governing powers, as well as requests to have government officials patronize events or inaugurate new establishments. These interactions constituted a tapestry of connection with State actors intended to build amicable bridges of "information, assistance, and dependency" between these small Indo-Mozambican sub-groups and powerful mainstream government interlocutors.

For example, even before the large-scale invasion of Portuguese territories by Indian authorities in 1961, there was a smaller invasion into the Portuguese enclave of Dadra in the early 1950s. While it was not mentioned in the oral stories I collected, the national archives retained a significant number of documents from organizations and municipalities in the region that showed support to the Portuguese State and disgust at the Indian State's incursion. Though most of the initial supporters were Indo-Mozambican Muslims, identified in the documents as Ismailis and Pakistanis, there were also records of large monetary donations made by Hindu groups to support the families of Portuguese soldiers who died in the military incursion. Archival documents showed that in multiple Mozambican provinces, Indo-Mozambican Muslims and Hindus joined their funds and submitted joint donations to the State organizations accepting donations. For example, one 1954 document N 2142/A-26a showed a combined total of 65.195, oo escudo donation from the Comunidade Indu (25.00o,oo), Comunidade Maometana (34.550,00) 
and the Pebane area population $(5 \cdot 645,00) .^{2}$ This is odd because, a large number of members were themselves from Portuguese territories in India and had to have some understanding of the poor colonial investment in these less prominent for areas, which did not benefit from the educational and economic infrastructure that Portugal installed in Goa. Instead, in Damao, Diu, Dadra, and Haveli, Portuguese presence and investments were minimal, which led many to leave India for Mozambican shores in the first place.

In talking with an interviewee who declined to be taped, he admitted that when his family first came to Mozambique, they had to teach themselves Portuguese, because in Diu his family only spoke Gujarati (ANONYMOUS, 2017). He represents members of this community that were well aware of their cultural proximity to Indian Gujaratis and the poor infrastructure left in colonialism's wake. Were that not the case, then the very civic purpose of the Comunidade in LM/Maputo would be in question.

I can only assume that this public display of support for the Portuguese military, the State enforcer of a colonial structure that did not benefit Indo-Mozambicans in these marginalized regions, was a ploy to align themselves with the State actors for protection from those very same State actors. Logically, the colonial regime was skeptical of Indo-Mozambican loyalties and this act of philanthropy was perhaps just an Indo-Mozambican attempt to purchase belonging and to stave off State reprisal.

\section{INDO-MOZAMBICAN RELIGIOUS ORGANIZATIONS AND THEIR MEMBERS}

Over the late $20^{\text {th }}$ century, some of the prominent Muslim organizations with large Indo-Mozambican membership included the Aga Khan Building (founded in 1941), the Escola Mahometana (also spelled "Maometana", translated as the "Mohammedian School" inaugurated in 1903) (ZAMPARONI, 1999, p. 214), and the Central Mosque on Rua da Gavea (built in 1887). Archival data shows their constant interaction with the State on a variety of levels, i.e. requesting financial sponsorship,

2 N2142/A-26a SA/ML - Adito ao oficio N 2116/Aa26a) de 10 de corrente. Dated Sept 14 1954 . 
soliciting government participation in events, and seeking permission to build or rebuild parts of its edifice. Oral narratives and archival records further show that these institutions served as sites that supported members in exploring and affirming their ethno-religious identity, as well as expanding their commercial footprint.

Of the thirty some individuals I spoke with for the larger study, Ibtihaj was the only interviewee who actually had attended one of these Islamic institutions and she spoke candidly about her childhood experience studying at the Escola Mahometana. Though her biological mother was Mozambican, the mulatta daughter of an Indian father and a Black Mozambican mother, Ibtihaj was raised by her stepmother who hailed from Pipodara and her father born in Ghandar - both Gujaratis and both Indian passport holders. Her experience as one of 8o pupils in the 196os was deeply connected to her Indo-Mozambican Muslim identity and her parents' insistence that she inherit as much of that cultural continuity as possible, even in Mozambique's Diasporic context.

I: When my father registered me in the school on Queen Dona Leonor street in front of Casa Fabião, in Alto Maé, I went dressed in pants and a shawl [traditional Indian dress]. Two days later, the teacher, who was a Portuguese professor, said to me "After today, you cannot dress like that. You have to come with a short dress. Do not wear a shawl or pants. Only come wearing a dress". I said, "ok". I went home and told my father [...] My father, on that very day, registered me in the Escola Mahometana, there in the Community Mahometana, because there we could go dressed in pants and shawls. It was a Muslim community. They taught Gujarati. They had a professor on one side who taught Gujarati and on the other side they had Muslim mullahs that taught Islamic things - how to make Salat, we studied the Quran, we learned how to obey the Quran, these things. On the other side, they taught Portuguese and there was a room with a Portuguese professor. I still remember my teacher's name, Virgínia Amélia Vaz Martins. She was the professor and the director of the same school [...].

$\mathrm{N}$ : Was the school mixed with people of Indian origin and Blacks too?

I: No, at that time, they could not enter. It was just Indian Muslims, only. Neither Whites nor Blacks could enter. (IBTIHAJ, 2015)

This racial exclusivity of the Escola Mahometana would later evolve towards integration by the 1980 s, but at the time of Ibtihaj's youth Indo-Mozambican Islamic organizations served multiple purposes. Its religious elements were just one component and perhaps not even the most important. Instead, these physical spaces allowed individuals to bring together the transnational elements of their identities in a self-affirming environment. The utility of these spaces expanded well beyond spiritual benefit. 
Instead, Indo-Mozambican Islamic organizations also served as banking and lending institutions for their members' financial needs. For example, Joana Pereira Leite and Nicole Khouri's 2013 in-depth study of the Ismaili community in Mozambique explored how the deportation of Indian citizens from Mozambique after the Indian invasion of Goa in 1961 created a window of commercial opportunity and advancement for Ismaili business owners. Quite a few Ismailis took advantage of loans through the Aga Khan organization to purchase businesses that had been seized from Indian passport holders, mostly Hindus. Businesses were cheaply auctioned off by the Portuguese colonial authorities. Leite and Khouri's text reads,

\footnotetext{
Take note that the Goan crisis, forcing the expulsion of Hindustani merchants from the colony, offered new business opportunities for Ismaili families. In fact, oral sources outside of the [Ismaili] community attest that it was at interesting prices that some Ismailis acquired establishments that had belonged to Indian citizens, who had been forced to abandon the colony. (LEITE, 2013, p. 103)
}

Data showed that despite the forced removal of Indian passport holders from the country, in just the decade between 1960 and 1970, the capital city's population grew from 178,565 to 383,755 , presenting a strong customer base for resident business owners to expand and profit (LEITE, 2013, p. 103).

These are just examples of the self-promoting role that Islamic Indo-Mozambican institutions fulfilled over the late $20^{\text {th }}$ century, when their membership was exclusively Indo-Mozambican. As in the example of the Ismaili commercial solidarity, it is important to understand that these institutions did not consider themselves to be acting in concert with other Indo-Mozambican institutions, even with those that shared the same religious affiliation. Though cordial proximity and strategic partnerships were not unheard of, institutional membership was siloed and benefits were afforded exclusively to in-group members.

In contrast to organizations for Indo-Mozambican Muslims, who hailed from a variety of Indian subcontinent locations and nationalities, Goan civic organizations were uniform in religious affiliation, geographic origin, and Portuguese nationality. Their organizations focused less on education, because they had already been grounded within the Portuguese educational and cultural curriculum back in Goa. Instead Goan organizations were more focused on culture and class. Similar to the Muslim groups, Goans had multiple institutions that represented 
different segments and sub-communities. Yet, each institution served as a site for cultural affirmation, as well as a gathering place to reminisce about and retain Goan customs.

Seated in her living room in Maputo, Conceição spoke candidly with me just months before her death about her own experience living in Mozambique. She was the daughter of Goan parents who moved to northern Mozambique from Guinea Bissau in 1963. Her father was an agronomist for the Portuguese government. She recalled the divisions between mainland Goans and those who lived in Katembe [the capital's peninsula extension]. Conceição very clearly explained that there were strict socio-economic separations even among the relatively small community of Goans in the capital and she hinted that different Goan cultural associations reflected caste divisions well into the 1980 s. Though Goans are all Catholic, the variety of Goan institutions most clearly reflected individuals' social status and their level of Portuguese assimilation. In our 2016 conversation, she explained:

C: [Goans] from Katembe, they were fishermen, and they don't mix up with civil servants. This started to decrease after [Mozambican] independence.

$\mathrm{N}$ : Were they all Catholics?

C: Yes.

$\mathrm{N}$ : So, the only thing separating them was social position?

C: I remember my parents would socialize with people from [the Department of] Agriculture, people from the Department of Finance, but not with the fishermen. The fishermen's wives would cook for us in parties. They are very good cooks. (CONCEIÇÃO, 2016)

These interpersonal social divisions were mirrored in the civic organizations that were created to represent these stratified sub-communities. Maria Branquinho's 2004 unpublished ethnographic research study entitled Socio-Cultural Identity Construction of Goans in Katembe, is particularly insightful in that it shows that even Goans regarded as part of the lower class, residing in periphery neighborhoods, established their own representative civic and religious organizations to meet local needs. Branquinho's study articulates how nationalization and independence in 1975 deconstructed established rituals and dismantled communal spaces in ways that are still felt today amongst Katembe's fishing community of approximatelyıo people. For example, before independence, Katembe Goans would worship in the chapel of the local Goan Club, but after independence the Club was seized by the Mozambican State and made into a school. They did have a small community center 
that was not seized, so they converted that into a church. In so doing, they avoided the expensive and time-consuming trip to the Maputo Cathedral on the mainland, the city's primary site for Catholic worship. While their worship at the national Cathedral could satisfy their religious needs, it would not satisfy their quest for a culturally exclusive location to encourage in-group comradery and to retain specific Goan rituals and customs. Yet, the mandatory racial integration of their new church in the post-colonial era, made even their new site only partially fitting for their community's ethnic needs. As Branquinho states, "Behind all this was Goan interest in creating a worship service of its own, as a way of affirming and distinguishing its socio-cultural identity". Eventually, ad hoc local Goan clubs, like the Clube de São Pedro and the Clube da Nossa Senhora das Merces, emerged in Katembe for particular Goan ceremonies and festivals. Yet, most of these clubs are not officially recognized organizations and appear to have no formal interaction with State actors (BRANQUINHO, 2003, pp. 31-35).

Though Goans' regional identity was inherently conflated with their religious identity, their secular divisions were divisive. When I talked with 81-years-old Joaquim at a waterfront café in Maputo, he rattled off a number of Goan organizations that existed in LM/Maputo in the $20^{\text {th }}$ century. He explained that while it was theoretically possible to be a member of multiple organizations, it was not common. Each institution had a different purpose, target membership, and geographical coverage area within the city.

J: Goans had their clubs. There was the Casa de Goa (House of Goa), which was where the Art Museum is now. The other was the Clube Desportivo IndoPortuguês (Indo-Portuguese Sports Club) that was near the police station in what is now Estrela Vermelha (a neighborhood named "Red Star"). Another was in the area of Escola Manyanga (Manyanga School). It was called the Casa da Cultura (Culture House). Before that it was the Associação dos Operários (the Workers' Association) [...].

$\mathrm{N}$ : What were the differences between them?

J: Those that were in Operário were mainly people who worked in that area, but there were other cultures too. Elites were in the Casa de Goa. In the Clube Desportivo it was those who played sports. (JOAQUIM, 2017)

These same Goan organizations no longer exist today. After Mozambican independence, Goan institutions largely dissolved under the pressure of State policies that promoted national unity and demonized religious and ethnic distinctions. Moreover, as many Goans departed 
Mozambique in the years surrounding its 1975 independence, those Goans left behind in Maputo had difficulty advocating for and maintaining institutional permanence given their severely diminished numbers.

In contrast to the Goan Christian and Indo-Mozambican Islamic organizations, the institution known today as the Comunidade Hindu (The Hindu Community; referred to here as the "Comunidade") was the singular institution that represented the Hindu community in the capital. As such, it stands out among other Indo-Mozambican institutions, making it ripe for deep dive research on how this particular organization navigated changing transnational pressures and shifting domestic policies. For over a century, it has been the only organization to represent the Hindu community in the nation's capital. It is the third oldest Hindu institution in the country, after the temples on Mozambique Island and Salamanga. 
Remate de Males, Campinas-SP, v. 38, n. 1, pp. 186-219, jan./jun. 2018 - 201
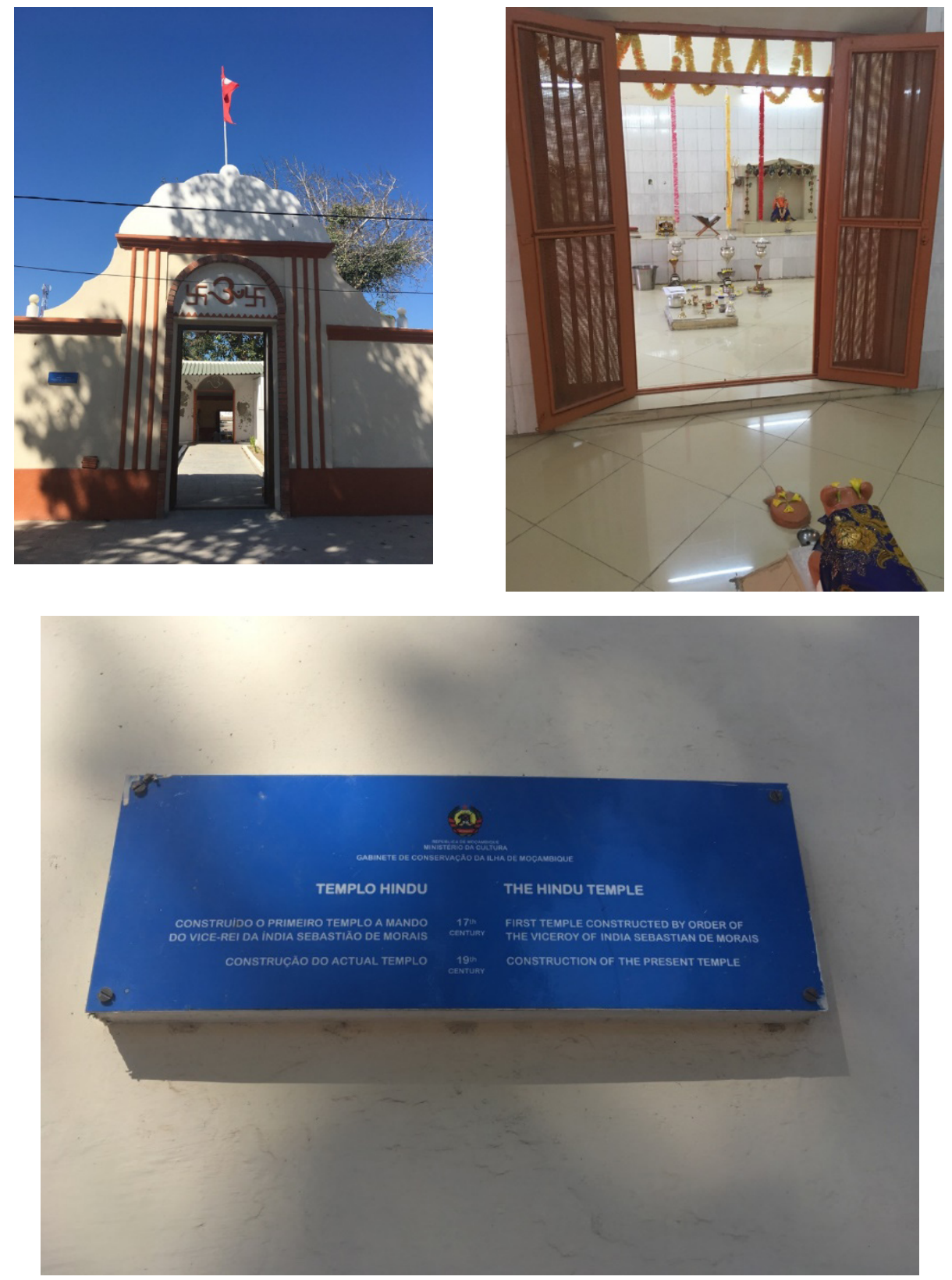

Figure 3: Mozambique Island Hindu Temple.

Source: Photos author's own (2016). 
Indo-Mozambican Interactions with the State (1947 - 1992): ... - 202
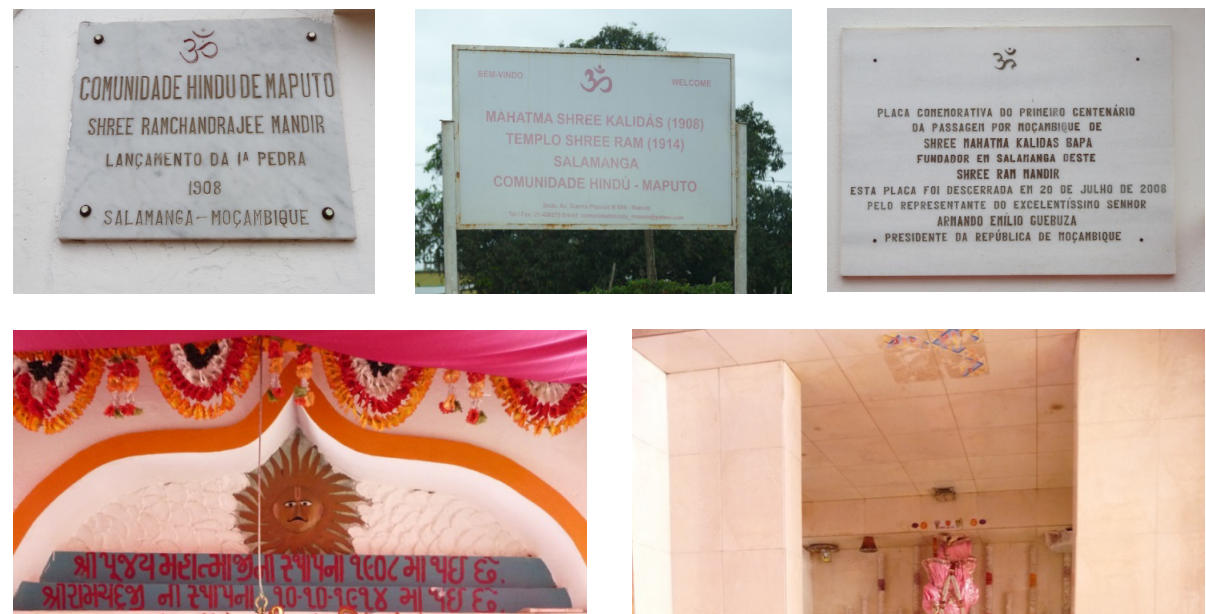

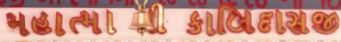
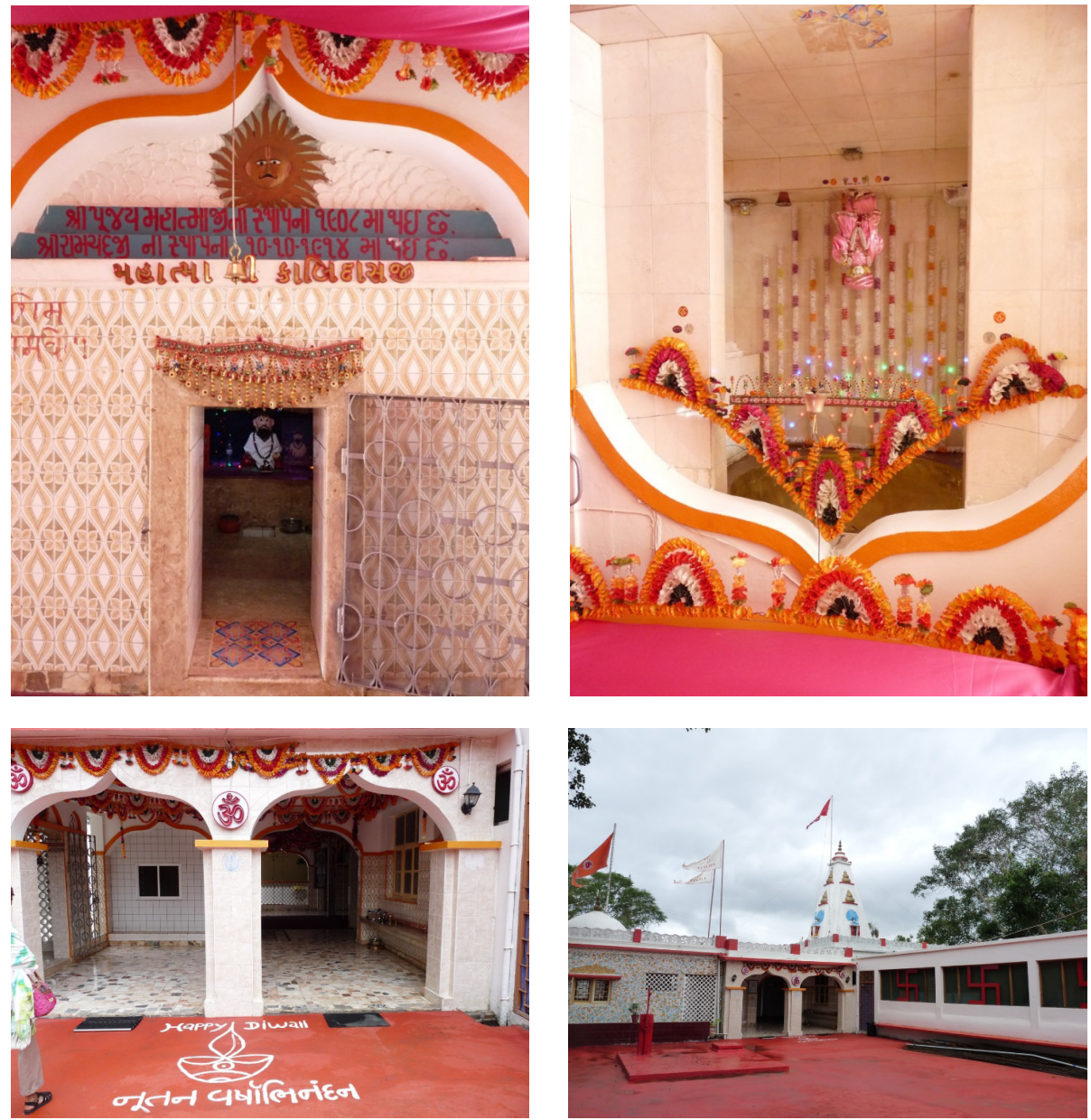

Figure 4: Salamanga Hindu Temple.

Source: Photos author's own (2016). 
Remate de Males, Campinas-SP, v. 38, n. 1, pp. 186-219, jan./jun. 2018 - 203
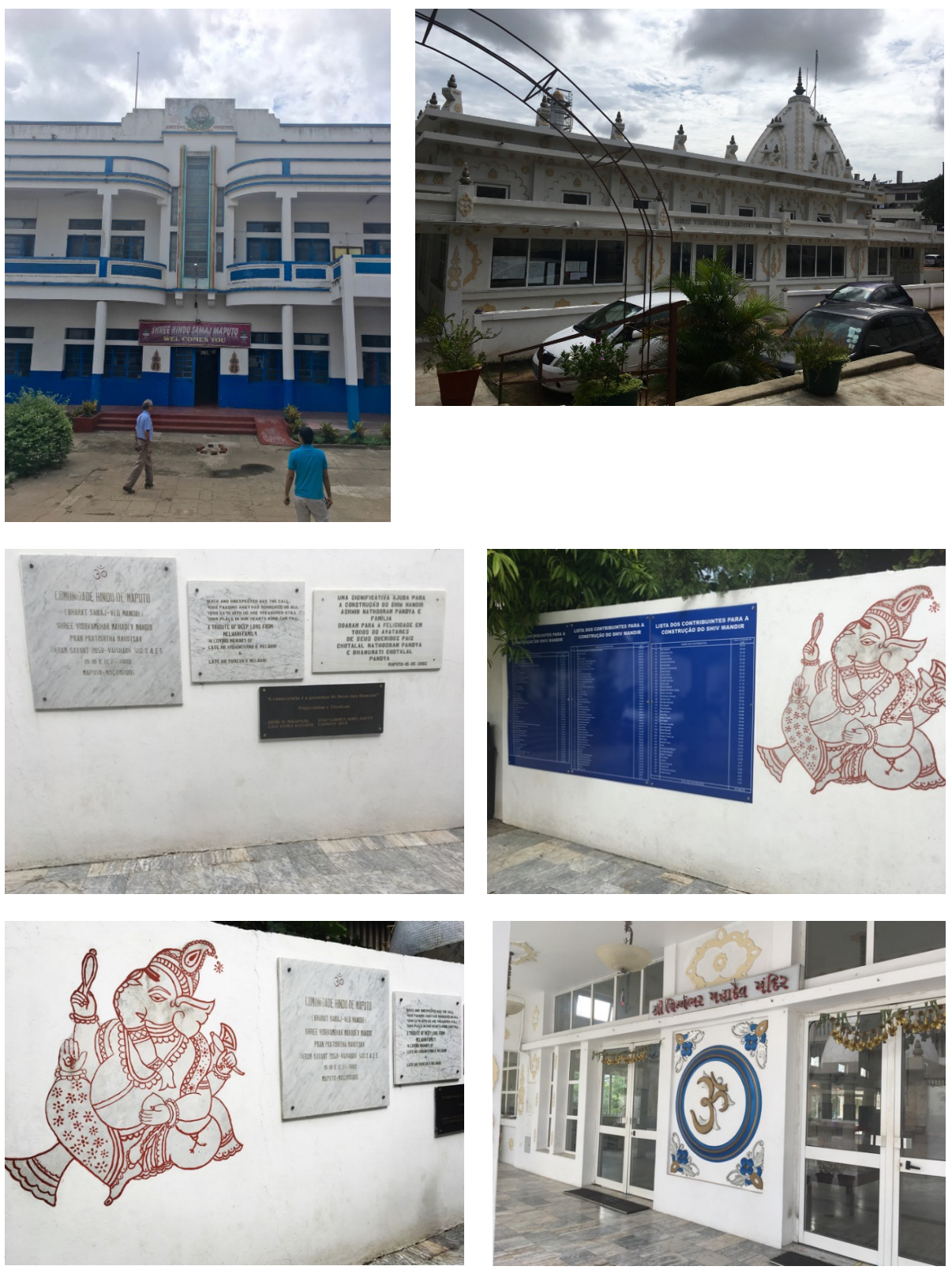

Figure 5: Lourenço Marques/ Maputo Ved Mandir Hindu Temple.

Source: Photos author's own (2017). 


\section{CASE STUDY - THE EVOLUTION OF THE COMUNIDADE HINDU IN LM/MAPUTO}

In LM/Maputo, institutional resilience varied across Indo-Mozambican associations of varying faiths, but herein I give special attention to the institution of the Comunidade Hindu (referred to as "Comunidade"). In light of forced migration, successive decolonization movements, and fluctuating citizenship rights, the Comunidade's continued existence today presents a valuable case study in the survival tactics employed by ethno-religious organizations to overcome pervasive vulnerability and to support members through serial insecurity. Individual members' oral narratives articulate how ethnic sub-identity was defined and divided as political and social shifts in the Indian Ocean and Lusophone worlds collided in the late $2 \mathrm{O}^{\text {th }}$ century.

Founding members of the institution of the Comunidade Hindu (herein referred to as "Comunidade") were largely working and middle class young men, having arrived in the late 1800 and early 1900 s to work as masons and builders in downtown LM; others were merchants and traders on varying scales. Initially, the Communidade's purpose was to serve this small segment of the Indo-Mozambican community in Hindu religious practice, as well as to teach in the Gujarati language. Most Hindu Mozambicans hailed from the former Portuguese enclave of Diu, as well as from the former British state of Gujarat - making Gujarati their mother tongue and a critical part of their ethnic identity. They represented a diverse mix of citizenships, with those from Diu being Portuguese and those from Gujarat being British, and some later being Indian. The Hindu Communidade passed membership on through family lines and many married, as caste and religiously appropriate, through connections made within the community. Further, the institution welcomed recent Indian arrivals, including newly arrived spouses from India and other parts of East Africa.

Again, Hindu parishioners joined their money and established the Ved Mandir in the early 1920 as a place of worship on par with the temples that preceded it. As published in the Official Bulletin (Series 8) on 21 Feb 1925, the statutes of the Nova Associação Hindo de Lourenço Marques (The New Hindu Association of Lourenço Marques) were shared with the public. Its goals were to 1) Promote the moral and intellectual development of its members, 2) Defend the legitimate rights and legal interests of Hindus, without regard to nationality, creating a place of worship, a 
hospital and a pharmacy, 3) Spread moral instruction through schools, conferences, reunions and literary propaganda, 4) Give protection, assistance and repatriation to members and their families whenever they do not have the means, as well as for any Hindu individual in need due to unemployment or other such circumstances, 5) Establish a lending library, for the use of members and their families, and entertainment activities that are compatible with the financial means of the Nova Associação Hindo: sports games etc. that are not contrary to the laws and ways of the country (ESTATUTOS, 1925, p. 2).

The Hindu religious space eventually extended to cultural education. According to the Comunidade's website and Facebook page, this element was founded as the Associação dos Trabalhadores Hindus "Bharate Semaj" (Association of Hindu workers - Indian Society) in 1932, and shortly after became a legally recognized institution. The Official Bulletin from January 1933 named the Bharate Semaj's goals as very similar to those established by the 1925 manifestation:a) Provide members with education, instruction and recreation, based in a day school, to be attended by minor descendants of the members, and an evening school for adults, who will receive primary education in Portuguese and Gujarati language, the sacred doctrine of the Vedas, the establishing of a small library for use by members and their families, and a playground, b) Assist members and their families in case of illness, by establishing an infirmary where they can receive treatment, c) Assist members who are unable to sustain themselves and their families due to unemployment or other unforeseen circumstances, d) Assist widows and children of deceased members, e) Defend the rights and legitimate interests of members (ESTATUTOS, 1933, p. 12).

Later, the cornerstone was laid by Swami Bhawani Dayal Sanyasi on the 1933 Vedic center. And by 1943, a local Hindu merchant broke ground on the new Indian School construction. The building was inaugurated in 1945. Thereafter, the space became known as the Bharat Samaj Ved Mandir, uniting its mixed-use purposes within its very name. Soon after, Bharat Samaj began to absorb the aftershocks of geo-political shifts in the Indian Ocean region and it began to take on new names and institutional aims to manage the changes of Indian independence in 1947, the annexation of Portuguese India in 1961, Mozambican independence in 1974, and the Mozambican civil war from 1977 to 1992 (COMUNIDADE, [s.d.], [s.p.]). 
Before 1947, citizenship on the Indian subcontinent was a tripartite of European nationalities: British, French and Portuguese. Additional citizenship choices emerged after partition: Indian and Pakistani. Most Indo-Mozambicans residing in LM/Maputo were Portuguese and the emergence of new nations across the Indian Ocean did not trigger a migratory or identity shift. However, for a small minority, Mozambique (and other East African countries) served as a site of sanctuary from the violence and insecurity of India and Pakistan's emergence. Nazar Abbas, the previous Deputy Chief of Mission of the Pakistani High Commission (1986-90), offered a summary in his previously published writings on the history of relations between Pakistan and the Portuguese overseas colony of Mozambique.

Under the Portuguese colonial rule there was no let or hindrance in the movement of people between Mozambique (declared an overseas province of Portugal) and the Portuguese enclaves in India. Merchants from Diu had settled on the island of Mozambique in early 1800 . Hindus from Diu, Sunni Muslims from Daman, others from Goa, migrated to Mozambique as small traders, construction workers and petty employees. Many Gujaratis moved from South Africa to Mozambique in the latter half of the $19^{\text {th }}$ century. None of these sub-continent people were from the present-day Pakistan. Even after the Independence of India and Pakistan in August 1947 there was no known Pakistan passport holder living in Lourenço Marques or any other part of Mozambique. (ABBAS, 2015, [s.p.])

The lack of Pakistani passport holders in Mozambique, however, did not mean that Indo-Mozambicans were not affected by the political circumstances that would partition the Indian-subcontinent. The $1940 \mathrm{O}$ was a time ripe for travel between India, Pakistan, and Mozambique, and many Indo-Mozambicans trace their family origins in Mozambique to travelers who migrated around this 1947 benchmark. Nevertheless, pre-1947 internal divisions among Indo-Mozambicans were acknowledged within the larger Indo-Mozambican community, but not publicly displayed to outsiders until they were politically foregrounded by the events of 1961 and 1974. As different Indo-Mozambican sub-groups cleverly adapted their identity, citizenship, and migration to cope with the instability facing their subgroups, it became clearer that each had a different trajectory based on individual agency and options for emigration.

The end of the Portuguese empire in India in 1961 was definitively the most transformational moment in the $2 \mathrm{O}^{\text {th }}$ century for Indo-Mozambican migration patterns and identity formation. As the 1950s came to a 
close, the Indian government officially raised with Portugal the topic of ending Portuguese colonialism in India. Portuguese insistence that ceding its Indian holdings was not up for discussion led to increasing hostility among the two nations and had direct ramifications on Indo-Mozambicans' migration, identity and citizenship (SILVA, 1976, pp. 5052).On December 18, 1961, the Indian government launched "Operation Vijay", a professional military operation that resulted in the invasion of the three enclaves. Portuguese soldiers were outnumbered and forced to relinquish the land and forts to Indian authority. Despite Indian reports of less than a handful of causalities, according to Diogo Moço's thorough study of Portuguese prisoners of war "Prisioneiros na Índia: 1961-1962" stated that Portugal's military police calculated 1,018 people as dead, injured, or disappeared. Countermeasures were taken throughout the entire Portuguese empire, but ultimately 2,274 Indo-Mozambicans were interned in deportation camps in Mozambique" (MOÇO, 2012, p. 55). These recent figures contrast sharply with those found in the 1963 edition of "Africa Today", which reported that 15,000 Indians were arrested or interned throughout the country (SPECIAL, 1963, pp. 12-13).

Group identification became vitally important during this period and stratification among Indo-Mozambican sub-groups took on drastically different proportions. The most affected Indo-Mozambican sub-group through this period were Hindus. Indian passport holders were overwhelmingly Hindu merchants, who had few allies outside of the Indian State. The majority of Christian Indo-Mozambicans were of British or Portuguese citizenship; Muslims appealed to their local Mozambican religious community for refuge and to the Pakistani government for reprieve. Hindus, however, were considered to be Indian loyalists by definition and were disproportionately represented in the scores of Indian nationals forced into deportation camps. The majority were forcibly removed, drastically reducing their population and strength in LM/Maputo thereafter.

To cope with geopolitical changes of the time, the Comunidade changed its name and stated purpose multiple times over this period to ensure its own survival as an institution and to solidify its value as a site of cultural significance in the Mozambican national context. The loss of a significant portion of its membership signified a failure in the institutional framework, such that it could not protect its members or broker a compromise to prevent their forced removal. After the Portuguese 
held territories of Goa, Damao and Diu were forcibly integrated into the Indian Republic in 1961, the Comunidade officially distanced itself from India. The remaining members were principally Hindus from Diu who maintained their Portuguese nationality and thus were able to continue on in Mozambique under Portuguese rule. This period of bifurcation by nationality subordinated the institution's founding pan-religious mission. An organization once united under religion found itself abruptly splintered along the fault lines of nationality.

By 1968, the organization was known as the Associação Luso-Ariana de Maputo (the Luso-Arian Association of Maputo). The Official Bulletin from that year shows a marked shift away from its founding goals and an approximation towards Portuguese acculturation and assimilation. The November 1968 document reads: "Associação Luso-Ariana de Maputo, founded on 14 January 1933, under the denomination of the Associação dos Trabalhadores Hindu 'Bharate Semaj', is an association of a sporting, recreational, cultural and benevolent character" (PORTARIA, 1968, p. 1.712). It goes on to outline its goals, which for the first time show both nationalist assimilation, and Portuguese political alignment. Gone are its advocacy elements. It reads:

a) Spread to its members education, instruction and recreation, developing in them a sports practice and facilitating for them distraction and culture, b) Delivering primary education in Portuguese language, c) Stimulating and assisting members in their initiatives to manifest their national and collective interests and to promote their moral virtues and the progress of the Portuguese Nation, d) Assist members and their families in cases of illness, establishing the necessary assistance services, e) Assist members who are unable to sustain themselves and their families due to unemployment or other unforeseen circumstances, f) Assist widows and children of deceased members. (PORTARIA, 1968, p. 1.712)

To show their alliance with Portuguese nationalism and the State, this distancing through naming was very important. This particular name change served two purposes. First, since the Hindu religion is believed to have originated with the Aryans, it was an accurate reference to their religious identity that shifted attention away from Hinduism, a term that was a defining element in the national identity of India. Thus, there was effectively no religious sacrifice in this name change. However, the name shift served more of a purpose in signaling alignment with the White Portuguese elements of society that were holding steadfast to the last years of Portuguese colonialism in Africa. After years of Nazi and Fascist 
references to the Aryan race, the term remained attached to the White race and Caucasian identity. The connotation of the word "Aryan" signaled an approximation towards the Portuguese State and its White supporters and a distancing from the growing Brown and Black peoples around the world who aimed to dismantle the last vestiges of colonial empire; this included the Indian State and its leadership of the non-aligned movement and moral support given to African nations seeking independence. Despite the Comunidade's attempts to remain politically aligned with the governing State powers and to reassure the State that their education and cultural aims were completely apolitical, the organization and its membership continued to be regarded with wary suspicion by the Portuguese State.

The combined name changes and goal shifts pivoted the organization away from its originating principles of cultural and religious education, as well as advocacy for the legal rights of its members. Instead, the assimilationist character of this particular institutional shift suggests a reactionary gesture to appease Portuguese colonial powers, who - after all - had just deported many of their members and seized all their assets. Perhaps, the shift was an acceptance of the organization's impotence in this regard. Remaining members were well aware of the futility of any such advocacy efforts, given the State's harsh stance on Indian aggression. Instead, they sought to preserve what was left of their organization and its membership, by taking an apolitical stance abandoning a platform of members' rights and embracing cultural assimilation to Portuguese language and culture.

In anticipation of independence and the introduction of socialism, many people departed the country well before 1975 to secure their place in Portugal. Among them, many of the remaining members of the Hindu community saw the end of Portuguese rule as a threat to their physical and economic well-being. The exodus of Portuguese passport holders from Mozambique spanned from approximately 1973 to 1977. And a significant portion of the Comunidade's members were in that number. According to the Comunidade Hindu of Lisbon's webpage, their activities were only ad hoc until 1975, when the decolonization of Mozambique brought over 9,ooo members and 800 leaders to the metropolitan areas of Lisbon and Porto. By 1982, these Indo-Mozambican expatriates in Portugal secured legal rights to assemble, as well as physical installations in which to continue their activities (COMUNIDADE, 2016, [s.p.]). 
Meanwhile in Maputo, as of 1977, the institution's name was changed again to the Clubede Desportos da Umbila (TheSports Club of Umbila). This change was likely prompted by the independent government's completely oppositional stance to any religious or ethnic divisions. This new name cloaked the identity of its membership, reducing the organization to a mere sports club. "Umbila" itself is a type of wood indigenous to Mozambique. I have not found any particular reason why this name was chosen or its strategic significance in any other terms other than to completely divorce it from its genuine purpose of ethnic and religious identification. If the 1968 shift to remove advocacy and Indian identity were gestures to appease the Portuguese government, this latest shift to remove all elements of identity whatsoever was perhaps the most sterilizing of all. This pre-emptive effort, like those before it, did not protect the organization from State aggression.

Deni, an active member of the small business and Hindu religious communities, was the only remaining member of his family residing in Mozambique by the time we spoke in his shop in 2017. The son of a Hindu tailor who came to Mozambique in 1920, Deni recalled how he, aged 17 , and his older brother saved their father's business and coped with Portuguese colonialism, all while his parents and younger siblings were deported to India in 1962. His narrative also described other moments of seizure of the Comunidade's buildings, which had not been previously explored in the archival and historical documentation I found. He explained how through interpersonal relationships with powerbrokers, the Comunidade was able to regain its physical spaces and still maintain a relationship with the State. Much of this harkens back to the analysis of Penvenne above, which attests that ethnic belonging held currency in navigating access to State and communal resources. Last, his narrative raises questions of nationality that emerged in the late 1980s. We see the Comunidade as an organization that shifted from a pan-Hindu platform that disregarded nationality in 1925, to a pro-Portuguese organization in 1968 , to a 1980 institution conflicted by the limitations of Mozambican nationality and a community that is today (re)negotiating its relationship with Indian nationality and Diaspora belonging.

D: In 1975, there was independence. Samora Machel gained power. The first encounter we had with him in the presidency, he said that Mozambique was free and independent. Whoever was born in Mozambique was Mozambican. There was religious freedom but with an orientation towards Frelimo [the ruling party]. We could not independently make our own places of worship. We had to come together and become a religion. The Christian council unified 
and became one. The Muslim community divided into three: Comunidade Mahometana, the Islamic Council and the Islamic Congress. The Comunidade Hindu became one from the Rovuma to Maputo [throughout the entire country]. We were always called to the General Assembly. There was a proximity with the government. They treated us as equals [...].

The ideology of Samora Machel was very good, but poorly interpreted [...] Communism is very good when it's interpreted correctly. But here it was used for opportunism [...] The schools closed, were nationalized. Anything you wanted to do required requesting authorization. There was a school that was Portuguese, but when there was the program of Damao and Diu [I assume this means Indian invasions between 1950 s and early 1960s], many Indians could not take care of the school and the Portuguese government nationalized it. They gave us only a big room to hold our religious ceremonies. When FRELIMO came, they did the same thing. In 1982, we fought to maintain it. We expressed to the government our interest in having an installation to pass on to the next generation. We sent a letter to Graça Machel [the first lady]. But the story was the same. They said that we could not keep the installation where the Portuguese school was located because children from the neighborhood were already studying there. The only solution was the construction of a new school for the kids. At that time, there was no money for that. We only had enough to eat. At that time there was a doctor [assumed to be a member of the Comunidade] who treated the Mayor and he spoke to him about the issue. He explained that this would be difficult for us. After that we gained new installations that were given to the Comunidade Hindu [...] Our community is small. In the whole country, there are only 1,500 or 3,00o Hindus, maximum. I mean those who were born here.

$\mathrm{N}$ : So how was it in 1982?

D: We got our new installations. We started the Comunidade Hindu.

$\mathrm{N}$ : This was a group of how many people?

D: We were about 20 to 25 people. We were young. We had help from the [Mozambican] government. There was a Department for Religious Affairs. When the Indian Embassy [High Commission] opened, we went to them for assistance whenever there were difficulties. They sent books.

$\mathrm{N}$ : The Indian government helped?

D: This was much later. I went to India to drop my mother [with relatives] and I brought back books from pre-Kindergarten to $4^{\text {th }}$ grade. We had to make photocopies of the books. When we opened in 1982, we had 500 students. Now in 2017, we only have 5 . Now the majority of the 500 alumni are doctors, engineers, and economists. Today we are proud of that sacrifice.

$\mathrm{N}$ : The Comunidade receives outside funding?

D: No. Once we were called to the Ministry of Justice, because they wanted to know how we sustained ourselves. It was by donations. Until now, no one has helped us.

$\mathrm{N}$ : So, there is no connection with the [Hindu community] outside of the country?

D: They say that we are Mozambicans. Even though we are of Indian origin, we are Mozambican. They say they cannot help. The new government of India is getting closer to us a bit. Now that they have the OCI [Overseas Citizenship of India] card. With this card, we can always go to India whenever we want; we 
can live there without a visa. Many people who have a connection with India already have the card. (DENI, 2017, [s.p.])

Just as the institution's educative purpose and its unifying powers came under suspicion from both the Portuguese (pre-1975), it did under Mozambican (post 1975) federal leadership too. Despite exhaustive review, I was not able to nail down the exact dates or justifications to explain why, but shortly after Mozambican independence, the institution's activities were suspended and its installation was seized again. The institution's current website and oral stories attest that at the time of nationalization, after Mozambican independence, the building that was the headquarters was seized by the State and converted into a public school "Escola Primária Sá da Bandeira”. It was only in the late 1980s, with the creation of the federal Department of Religious Affairs that members were able to appeal to have their building returned to them. And it was not until 1998 when Hindu merchants and activists' efforts combined to successfully restore ownership back to the Hindu community for its original purpose (PEREIRA, 2011, [s.p.]). Since then, the institution has been back in Hindu hands, serving its religious and educational purposes, under the title of the Comunidade Hindu de Maputo (COMUNIDADE, [s.d.], [s.p.]).

The singularity of the Comunidade as the only Hindu association in town made it a fixture of cultural life for Indo-Mozambican Hindus. This same singularity perhaps made it an easy target for State-led repression. In speaking with Deni, I learned that he was an active member of the Comunidade and had been part of the movement to restore the Comunidade's building back to members in the 1990s. According to his memories, the organization did not dismantle during this period that its physical space was seized. Rather, it was an organization without a specified location, but nevertheless was still an active informally and individuals represented the Indo-Mozambican Hindu community whenever the State or its members requested.

For Comunidade members, past and present, the institution itself holds socio-cultural significant value and is a physical reminder of their struggle for inclusion and representation in the capital. The constant circulation of members in this space allowed for the continuity of socio-cultural connection among members of this very tight-knit Hindu community that was cyclically under State vigilance and social gaze. This transnational space was arguably the only non-familial site of 
unconditional belonging afforded to LM/Maputo's Indo-Mozambican Hindus.

\section{CONCLUSIONS IN CONTEXT}

The history above shows the Comunidade's oscillating bouts with allegiance to and distance from the State. Rhetorical performance in speeches recorded over and over again this community's continued reference to the superiority and racially inclusive stance of the incredibly racist Portuguese colonial empire in Africa. As in the example of Dadra, the contradictions in their actions and the logical sentiment of the day leads me to conclude that they did not genuinely believe everything they espoused, but instead understood and valued the currency of rhetorical alignment. It was through political maneuvering and exerting group agency that Indo-Mozambican Hindus survived the changes of the late $2 \mathrm{O}^{\text {th }}$ century and preserved their institution for future educational, religious, and cultural use. For the Comunidade, serving as a unifying body made it easy for interlocutors to access this culturally distinct ethnic and religious group. This singularity, however, also made the Comunidade vulnerable to State aggression. Pro-active steps to change the institution's name and purpose did not convince State actors of the organization's neutrality. Yet, despite its diminished membership and sporadic seizures, the Comunidade Hindu is the only Indo-Mozambican organization that survived until today with its original purpose and member demographic intact.

As demonstrated by the case study of the Comunidade Hindu, Indo-Mozambican civic associations held deep socio-cultural value for Indo-Mozambicans in LM/Maputo. Through these collective organizations, Indo-Mozambicans were advocates and advocated for in ways that perhaps would not have been possible individually. Not only did these institutions represent ethnic and religious identities, but they also served to educate and perpetuate cultural continuity in the Diasporic context. The particular changes to the Comunidade over time are just another lens through which to analyze the coping mechanisms and survival strategies generally embraced by Indo-Mozambicans to maintain their presence in Mozambique's urban capital, despite multifarious State actions to incentivize their departure and diminish their presence over the $20^{\text {th }}$ century. 
In conclusion, the socio-cultural value of civic associations in Maputo was deeply important for Indo-Mozambicans. Not only did these institutions serve as safe spaces for members to manifest transnational ethnic and religious identities, but they also served as mechanisms of cultural continuity for future generations. For outside communities, even those that were Indo-Mozambican, but not of the same sub-identity, these organizations stood as unifying bodies that allowed for easy access to commune with an otherwise small group of disparate individuals, who were otherwise socially and physically segregated in Mozambique's urban spaces.

Aside from its in-group service as educational and benevolent associations, these civic institutions also served as organizational intermediaries between individuals and the State, whenever the State allowed it. For the Comunidade, the institution served as a singular point of contact making it easy for interlocutors to access the Hindu sub-group, whose belief system and cultural traditions were largely foreign to all outsiders, including other Indo-Mozambicans. This singularity, however, also made the Comunidade particularly vulnerable to attack by State actors that were unconvinced of their political neutrality. Pro-active steps to change the institution's name and purpose did not protect it from losing its physical assets throughout the $2 \mathrm{O}^{\text {th }}$ century.

In comparison, Islamic Indo-Mozambican institutions had multiple organizational bodies that have survived until today, but have largely become ethnically integrated. Thus, they have lost the exclusive nature of their Indo-Mozambican ethnic and regional origins. Similarly, Goan institutions were condensed and absorbed into multi-racial Catholic organizations that are similarly now divorced of their transnational and ethnic components; in fact, the Comunidade Hindu is the only organization that has been able to retain both its original purpose and membership demographic.

During the late $2 \mathrm{O}^{\text {th }}$ century, the Indo-Mozambican community in LM/Maputo absorbed the aftershocks of four particular geo-political shifts in the Indian Ocean and the Lusophone world: Indian independence from Britain in 1947, the annexation of Portuguese India in 1961, Mozambican independence in 1975, and the Mozambican civil war from 1977 to 1992. Representational organizations changed their name, membership, and purpose over this period to ensure their institutional survival and to solidify their transnational cultural significance. Institutional resilience was 
manifested by Indo-Mozambican associations of varying faiths, though forced migration under Portuguese colonialism and forced integration under African socialism successively threatened organizations' ability to effectively operate. Such ethno-religious organizations attempted to help their constituents overcome pervasive vulnerability and to gain access to highly coveted political capital. Indo-Mozambican associations served as transnational sites where ethnic identity and migratory agency were cyclically constructed and deconstructed to respond to and cope with federal power structures and local demographics. It is within them that ethnic sub-identities were articulated to and retained by in-group members and it is through them that the diversities of the Indo-Mozambican experience in the capital was shared with the larger Mozambican society and the Lusophone world.

\section{INTERAÇÕES INDO-MOÇAMBICANAS COM O ESTADO (1947- 1992): INSTITUIÇÕES CÍVICAS E RELIGIOSAS EM LOURENÇO MARQUES/MAPUTO COMO LOCAIS DE AFIRMAÇÃO DE IDENTIDADE ÉTNICA E CONTESTAÇÃO MIGRATÓRIA}

Resumo: Utilizando dados etnográficos e de arquivo, este estudo argumenta que ao longo do século XX instituições religiosas e cívicas em Lourenço Marques/Maputo, Moçambique, serviram como espaços de contestação e de identidade transnacional para residentes moçambicanos de origem indiana e paquistanesa (aqui referidos como "Indo-Moçambicanos"). Durante esse período, os indo-moçambicanos absorveram o impacto de quatro mudanças geopolíticas particulares no Oceano Índico e no mundo lusófono: a independência da Îndia britânica em 1947, a anexação da Índia portuguesa em 1961, a independência de Moçambique em 1975 e a guerra civil moçambicana de 1977 a 1992. Este estudo explora a maneira como as organizações representativas mudaram seu nome, membros e propósito durante esse período para assegurar sua sobrevivência institucional e solidificar seu valor como um local transnacional de significado cultural. A resiliência institucional é contrastada entre as associações indo-moçambicanas de crenças variadas, com particular atenção dada à instituição da Comunidade Hindu (aqui referida como "Comunidade"). À luz da migração forçada, dos sucessivos movimentos de descolonização e da flutuação dos direitos de cidadania, a existência continuada da Comunidade representa hoje um valioso estudo de caso nas táticas de sobrevivência empregadas pelas organizações étnico-religiosas para superar a vulnerabilidade generalizada e apoiar seus membros, confrontando a constante situação de insegurança. As narrativas orais dos membros individuais articulam as maneiras como a subidentidade étnica foi definida e dividida, à medida que as mudanças políticas e sociais no Oceano Índico e na lusofonia colidiram no final do século XX. As associações indo-moçambicanas eram locais transnacionais, onde a identidade étnica e a agência migratória foram construídas e desconstruídas ciclicamente para responder (e lidar com) as estruturas de poder federal e as mudanças na demografia local.

Palavras-chave: Moçambique; migração; Diáspora Indiana. 


\section{WORKS CITED}

ABBAS, Nazar. Memoirs of an Ambassador. Karachi: Manzil, 2015.

ANONYMOUS DISCUSSIONS with the author. April 2017. (Field research)

ALLINA, Eric. Slavery by Any Other Name: African Life Under Company Rule in Colonial Mozambique. Charlottesville: University of Virginia Press, 2012.

ANTUNES, Cristiano. Location of Portuguese India. Wikipedia. Last modified Sept. 14 2012. Available in: <https://en.wikipedia.org/wiki/Portuguese_India\#/media/ File:Portuguese_India.PNG>.

ATAL, Yogesh. Outsiders as Insiders: The Phenomenon of Sandwich Culture - Prefatorial to a Possible Theory. In: The Indian Diaspora: Dynamics of Migration. Ed. N. Jayaram. New Delhi: Sage, 2004, pp. 200-218.

BASTOS, Susana Pereira. Mozambique, we didn't have Apartheid. Identity Constructions on Inter-Ethnic Relations During the "Third Portuguese Empire". Cadernos de Estudos Africanos, n. 9/10, 2006., pp. 77-99.

BERTELSEN, Bjørn 'Enge. Violent Becomings: State Formation, Sociality, and Power in Mozambique. New York: Berghahn Books, 2016.

BORGES, Charles J.; FELDMANN, Helmut. Goa and Portugal: Their Cultural Links. V. 7 . XCHR Studies. New Delhi: Concept Pub. Co., 1997.

BRANQUINHO, Maria. Processos de construção de identidade sociocultural: o caso da comunidade Goesa da Catembe. Dissertação (Mestrado em Antropologia) Universidade Eduardo Mondlane. Maputo, 2003.

COMUNIDADE HINDU of Lisbon [Facebook homepage]. Quem somos. 2016. Available in: <http://www.comunidadehindu.org/quem-somos/>. Accessed on: July 2, 2017.

COMUNIDADE HINDU de Maputo - Hindu Samaj. Available in: <https://www.facebook. com/pg/comunidadehindu.maputo/about/?ref=page_internal>. Accessed on: Feb. 14, 2017.CONCEIÇÃO IN discussion with the author, March 2016.

COUTO, Fernando Amado. Moçambique 1974: o fim do império e o nascimento da nação. Lisboa: Editorial Caminho, 2011.

DENI IN discussion with the author. July 2017. (Field research)

DRA. INÊS Raimundo in discussion with the author. April 2017. (Field research)

DUFFY, James. Portuguese Africa: James Duffy. Cambridge: Mass., 1961.

ESTATUTOS DA Associação dos Trabalhadores Hindus “Bharate Semaj”. Boletim Oficial de Moçambique, n. 2, 14 jan. 1933. 
ESTATUTOS DA Nova Associação Hindu de Lourenço Marques. Boletim Oficial de Mocambique, 21 fev. 1925 .

FINNEGAN, William. A Complicated War: The Harrowing of Mozambique. Berkeley: University Press of California, 1992.

FUCHS, Elisa. Moçambique: marcou-nos para a vida: Grupo de mulheres internacionalistas 1980-1984. Retratos e depoimentos. Maputo: Ciedima, 2014.

GAITONDE, P. D. The Liberation of Goa: A Participant's View of History. New York: St. Martin's Press, 1987.

GAYER, Laurent; JAFFRELOT, Christophe. Muslims in Indian cities: Trajectories of Marginalisation. New York: Harper Collins, 2013.

GUPTA, Pamila. Eyes Across the water: Navigating the Indian Ocean. Johannesburg: Unisa Press, 2010.

HEUBERGER, Gretchen. Transnational Belonging: The Effects of the Independence and Partition of India on the Indo-African Diaspora. Columbia Undergraduate Journal of South Asian Studies, New York (Columbia University), v. 1.1, pp. 75-90. Available in: <http://www.columbia.edu/cu/cujsas/Volume\%2oI/Issue\%2oII/Gretchen\%20 Heuberger\%20-\%2oTransnational\%2oBelonging.pdf>. Accessed on: Jan. 4, 2017.

HROMNÍK, Cyril A. Goa and Mozambique: The Participation of Goans in Portuguese Enterprise in the Rios de Cuama, 1501-1752.PhD dissertations (History). Syracuse, NY, 1977. Available in: <https://surface.syr.edu/hst_etd/57>.

IBTIHAJ IN discussions with the author. Oct 2015. (Field research)

INDIANS IN Mozambique. Africa Today, 10, n. 2, Feb. 1963, pp. 12-13. Available in: <http:// www.jstor.org/stable/4184388>. Accessed on: Feb. 16, 2015.

ISAACMAN, Allen F.; ISAACMAN, Barbara. The Tradition of Resistance in Mozambique: Anti-colonial Activity in the Zambesi Valley, 1850-1921. London: Heinemann, 1976.

ISAACMAN, Allen F.; ISAACMAN, Barbara. Mozambique: From Colonialism to Revolution, 1900-1982. Boulder, Colorado: Westview Press, 1983.

ISAACMAN, Allen. Mozambique: The Africanization of a European Institution, the Zambesi Prazos, 1750-1902. Ann Arbor, MI: UMI Books on Demand, 2002.

JOAQUIM IN discussion with the author. April 2017. (Field research)

LEFANU, Sarah. S is for Samora. London: Hurst, 2012. (Field research)

LEITE, Joana Pereira; KHOURI, Nicole. Os ismailis de Moçambique: vida económica no tempo colonial. Lisboa: Edições Colibri, 2013. 
MACARINGUE IN discussion with the author, June 2016. (Field research)

MAGAIA, Albino. Moçambique: raízes, identidade, unidade nacional: análise, comentários, textos escolhidos. Maputo: Ndjira, 2010.

MONDLANE, Eduardo. The Struggle for Mozambique. Middlesex, UK: Penguin, 1969.

MOZAMBIQUE. Município de Maputo. Conselho Municipal de Maputo. Perfil Estatístico do Município de Maputo 2004-2007. Maputo, 2007.

NANJIRA, Daniel D. C. Don. The Status of Aliens in East Africa: Asians and Europeans in Tanzania, Uganda and Kenya. New York: Praeger, 1976.

OISHI, Takashi. Indian Muslim Merchants in Mozambique and South Africa: Intra-regional Networks In Strategic Association with State Institutions, 1870s-1930s. Journal of the Economic and Social History of the Orient, v. 50, n. 2, 2007, pp. 287324[Web: pp. 6-7]. Disponível em:<http://www.jstor.org/stable/25165197>. Acesso em: 23 maio 2018.

PEARSON, Michael N. Port Cities and Intruders: The Swahili Coast, India, and Portugal in the Early Modern Era. Baltimore, MD: Johns Hopkins University Press, 1998.

PENVENNE, Jeanne Marie. African Workers and Colonial Racism: Mozambican Strategies and Struggles in Lourenço Marques, 1877-1962. London: Currey, 1995.

PEREIRA, Cristina. A herança de Kalidas. 6 Jul. 2011. Available in: <http://www.buala.org/ pt/cidade/a-heranca-de-kalidas>. Accessed on: Oct. 5, 2017.

PITCHER, Anne. Transforming Mozambique: The Politics of Privatization, 1975-20oo. Cambridge: Cambridge University Press, 2002.

PORTARIA n. 21, 6oo. Boletim Oficial de Moçambique, n. 48, nov. 30, 1968.

SILVA, Ladis da. The Americanization of Goans. Toronto: [s.n.], 1976.

SIMÕES ROQUE MOÇO, Diogo Manuel. Prisioneiros na Índia 1961-1962. PhD diss. Universidade de Lisboa. Lisboa, 2012.

SPECIAL CORRESPONDENT. Indians in Mozambique. Africa Today, 10, n. 2, Feb. 1963, pp. 12-13.

THOMAZ, Omar Ribeiro. Raça, nação e status: histórias de guerra e "relações raciais" em Moçambique. Revista USP, n. 68, 2006, p. 252. Available in: <http://www.revistas. usp.br/revusp/article/view/13496/15314>. Accessed on: May 4, 2016.

URDANG, Stephanie. And Still They Dance: Women, War, and the Struggle for Change in Mozambique. New York: Monthly Review Press, 1989. 
Remate de Males, Campinas-SP, v. 38, n. 1, pp. 186-219, jan./jun. 2018 - 219

ZAMPARONI, Valdemir. Monhés, Baneanes, Chinas e Afro-Maometanos: colonialismo e racismo em Lourenço Marques, Moçambique, 1890-1940. Lousotopia, 200o, pp. 191222. Available in: <http://www.lusotopie.sciencespobordeaux.fr/zamparoni.rtf>. Accessed on: June 20, 2017. 